\title{
CULTURAL HERITAGE AND THE DEVELOPMENT OF SUSTAINABLE TOURISM IN THE EJE CAFETERO REGION OF COLOMBIA
}

\author{
MirosŁaWA CZERnY, ${ }^{1}$ Ciro AlFonSO SERnA MENDOZA, ${ }^{2}$ \\ ANDRZEJ CZERNY, ${ }^{3}$ DIANA SOFÍA SERNA GIRALDO ${ }^{4}$
}

\author{
1 University of Warsaw \\ Faculty of Geography and Regional Studies \\ e-mail: mczerny@uw.edu.pl \\ 2 Universidad de Manizales \\ Director Doctorado en Desarrollo Sostenible \\ e-mail: redesomciro@hotmail.com \\ 3 Maria Curie-Skłodowska University in Lublin \\ Faculty of Earth Sciences and Spatial Management \\ e-mail: aczerny@poczta.umcs.lublin.pl \\ 4 Universidad de Manizales \\ Doctorado en Desarrollo Sostenible \\ e-mail:dssg15@gmail.com
}

\section{\begin{tabular}{l|l} 
JEL CODES & $\mathrm{Z} 32, \mathrm{Q} 2, \mathrm{Z} 0$
\end{tabular}}

ABSTRACT Heritage, as an element of culture, needs to be looked at in terms of its economic potential, and the opportunities afforded for local and regional economies to be reshaped. A cultural landscape, and particularly one promoted and prized by local people and incomers alike, may also serve as a heritage object. An undoubted example from this category is the area of western Colombia devoted to coffee-bean cultivation. Known as El Eje Cafetero, it has already received World Cultural Heritage recognition from UNESCO, and has become one of Colombia's most popular tourist destinations. The Eje Cafetero tourist region is often perceived as exemplifying a sustainable economy based on existing natural resources and cultural heritage in the landscape of Colombia's Western Andes. Local and regional authorities in the coffee region certainly boast plans and programmes for the development of tourism that recognises the exceptional social, economic and landscape features of this part of the country, and the ways in which they support this direction of development as opposed to any other (Martínez, 2006). In doing so, they draw on examples of other countries and regions around the world in which tourism is indeed a product for export (Getino, 1993).

The aim of the article is to analyze the role of cultural heritage in the development of tourism in the coffee growing region of Colombia. It is assumed that the promotion of cultural tourism in the rural region brings economic benefits to the local economy.

KEYWORDS cultural heritage, cultural tourism, sustainable development, least developed countries, Eje Cafetero 


\section{Introduction}

Heritage, as an element of culture, needs to be looked at in terms of its economic potential, and the opportunities afforded for local and regional economies to be reshaped. As Immanuel Wallerstein puts it, the cultural aspect to globalisation derives from the economic process, with the way in which it is perceived as linking closely with the stage of development the global system finds itself in (Kumar, Welz, 2001). Going further, the role of heritage in the process of contemporary economic development needs to be analysed as one of the manifestations of the production/consumption dichotomy.

A cultural landscape, and particularly one promoted and prized by local people and incomers alike, may also serve as a heritage object. An undoubted example from this category is the area of western Colombia devoted to coffee-bean cultivation. Known as El Eje Cafetero, it has already received World Cultural Heritage recognition from UNESCO, and has become one of Colombia's most popular tourist destinations. The aim of the article is to analyze and assess the impact of the development of cultural tourism on the development of a traditionally agricultural region, where the cultivation of coffee prevails

\section{Heritage and tourism}

In geography, work on heritage is first and foremost associated with the geography of tourism. There can be no doubt that growing interest in the way tourism around the world is developing and also playing a role in the economic restructuring of places and regions - is encouraging a process whereby both academic studies and planning practice attach ever-greater importance to the role of the cultural factor in development.

In seeking to analyse the development of tourism, Britton (1991) opted for presentation in the context of contemporary cultural and economic phenomena. He showed that groups and individuals shape their image (and also build identity) through the construction of a model of consumption that draws on local customs and practices. In the author's view consumption designates belonging to a defined social grouping (Britton, 1991). It is thus possible to observe fashion for the consumption of given goods or services. However, fashion for a given product fades and a new one makes its appearance, in this way attesting to the evolution of the consumption culture. If interest in heritage on the part of different groups in society is to be perceived in this way, then it emerges that fashion and the expectations of the given moment again do the shaping.

Apart from places serving a typical recreational function (i.e. they mainly offer the visitor ideal conditions for the so-called "R\&R"), the offer areas put before tourists also include many places whose main positive attribute is culture, be this of a material or non-material nature. Geographical studies approach this phenomenon from the point of view of the local development it is able to generate in given areas. And among the key factors capable of offering the necessary stimulation are community ties with a given place, as well as a strongly shaped regional identity. At the same time, the existence of attributes like local identity, specific features of a place and its inhabitants, the feeling of social bonding and so on are treated as elements raising the level of utility of a given 
place. This latter aspect proves particularly important to the development of tourism, in line with the concept that the level of interest in this, in a given place, is raised by the presence of items and aspects of cultural heritage (Ateljevic, 2000).

Market-related issues link up with the utility of heritage when it comes to achieving the objectives of tourism. Britton (Britton, 1991, p. 462) was already emphasising the exceptionally important role the advertising and marketing were able to play in developing public perceptions of a given place. He considered this an element of investment in the development of a place, or - to put it another way - in tourist space. In the advertising of such a place, the emphasis needed to be made on its unique nature, specific features, setting in relation to local tradition, and intimate association with the natural landscape present.

It is therefore in this sense that marketing of heritage for tourist purposes needs to stress that consumers (those paying visits) are acquiring (by visiting) a one-of-a-kind product, i.e. something unique that has been preserved or restored especially for them (Ateljevic, 2000). In line with views that are now the mainstream in the social sciences, the logic and rationality characteristic for the production of goods are now seen to translate into the sphere of free time, with great opportunities put in place for controlled (and also of course in some sense manipulated) mass consumption. That also means that the places created, whose development is assisted, are solely those in which effective marketing is present (Ateljevic, 2000).

Representatives of the Frankfurt School have resorted to the term "cultural industry" in addressing the phenomenon of the creation of an economic sector that focuses all of its activity on the management of people's free time (Ateljevic, 2000). The normal laws of the market are in operation here, and capital accumulation is a part of that, ensuring that a continuous stream of new ideas appears to allow accessible resources to be put in use, and managed, for tourism-related purposes (or still more generally, in relation to proposed ways in which free time may be spent). Simultaneously, a process of demand-stimulation is in operation, with this not merely reinforcing what heritage on the market has to offer, but also working to diversify it further.

The search for new products on the market that help with the pursuit of the "cultural industry" strategy draws even more strongly on the utilisation of known and catalogued heritage, as well as the search for new examples. Tourism thus treats heritage as its own particular kind of production system in which there is a steady inclusion of less well-known, more unconventional culture, people, places, behaviours and scenery (Britton, 1991, p. 454).

Thus, if heritage is i.a. something from the past that we select in the present as we seek to attain a contemporary goal (Graham, Ashworth, Tunbridge, 2000), then the ongoing process of offering society new representative items yet may last for a long while. However, the search for such items, alongside the inevitable over-exploitation of those that are discovered and rendered accessible to tourists has no option but to transform the heritage in question, and in the worst cases, to lead to its devastation and destruction. Furthermore, it is evident that the heritage in question is being put to use (or overuse) - by the consumer (on the one hand) and the entrepreneur (on the other) - in line with the concepts, values and needs of today. This is to say that, for example, the use made of heritage to achieve economic objectives a hundred years ago (when the level of social 
development differed from that seen today) was likewise different, e.g. being manifested in a fashion for antiquity and a desire to visit Egypt in the manner and circumstances which that era was able to provide for.

In general then, heritage as a resource being used in the local or regional development process is a genuine phenomenon, and, in the view of Britton (1991) this resource is brought within a specific tourism-related production system. And the manipulation ongoing in this context to maximise profit leads to the creation of a new place differing from the one that had been present before "tourist site" status was taken on. This phenomenon of the creation of new places or the farreaching transformation of existing ones, due to intensive tourist-related exploitation, boils down to what the literature terms "selling places" (Ateljevic, 2000) or even "the speculative construction of places” (Harvey, 1989, 1993).

Jackson and Thrift (1995) note that when given goods (products) start to extend beyond their normal functions as they assume cultural and symbolic (as well as merely economic) significance, a blurring of the production-consumption relationship starts to arise. It then becomes possible to refer to an unending cycle of interweaving between these two elements, as heritage is put to work in the generation of profit.

The consumption of heritage may be treated or understood as a public activity defined (and also subject to modification) by elites, and accepted, exploited and ultimately also consumed, by the masses. Indeed, for the consumption of heritage to take place, the process must be sanctioned by society, which itself implies legal regulation to allow for it, and institutions to monitor it. Likewise, the tradition, custom and instilled principles present in a given society must allow the act of consumption to go ahead. Ultimately, it may not contravene certain limits that ideology, religion and values continue to put in place. Thus, for example, Mecca remains closed to non-believers.

It should be recalled that, where heritage is referred to in terms of place, the perception may either involve a real item, or something that is only symbolic. In either case, different actors in the economy make use of it as they shape a defined image or portrayal of the heritage in question. This is naturally achieved via the media, but also tourist offices and agencies, local authorities, intellectual elites, and so on. All engage in iconography construction in respect of given landscape (or place), with consumers in their huge numbers then perceiving this as something evident and obvious (Ateljevic, 2000).

The two elements shaping a cultural region are social and cultural identity - which create and develop strong ties of affinity and solidarity within a given community that comes to make reference to these apparent virtues as it feels different from "outsiders", even if these live quite close by; as well as the place specific to the community in question - a defined piece of geographical space that has (or is perceived to have) features different from other areas all around it (Arango, Gaviria, 2008). 


\section{Coffee production in western Colombia}

It was in 2011 that UNESCO listed as World Cultural Heritage the unique landscape and culture of the coffee-cultivating region in the east-central part of the Colombian Andes known as Paisaje Cultural Cafetero. El Eje Cafetero is a part of this wider area, located in the Colombian Departments of Caldas, Risaralda and Manizales; and today this is one of the most-visited tourist destinations anywhere in that country about twice the size of France.

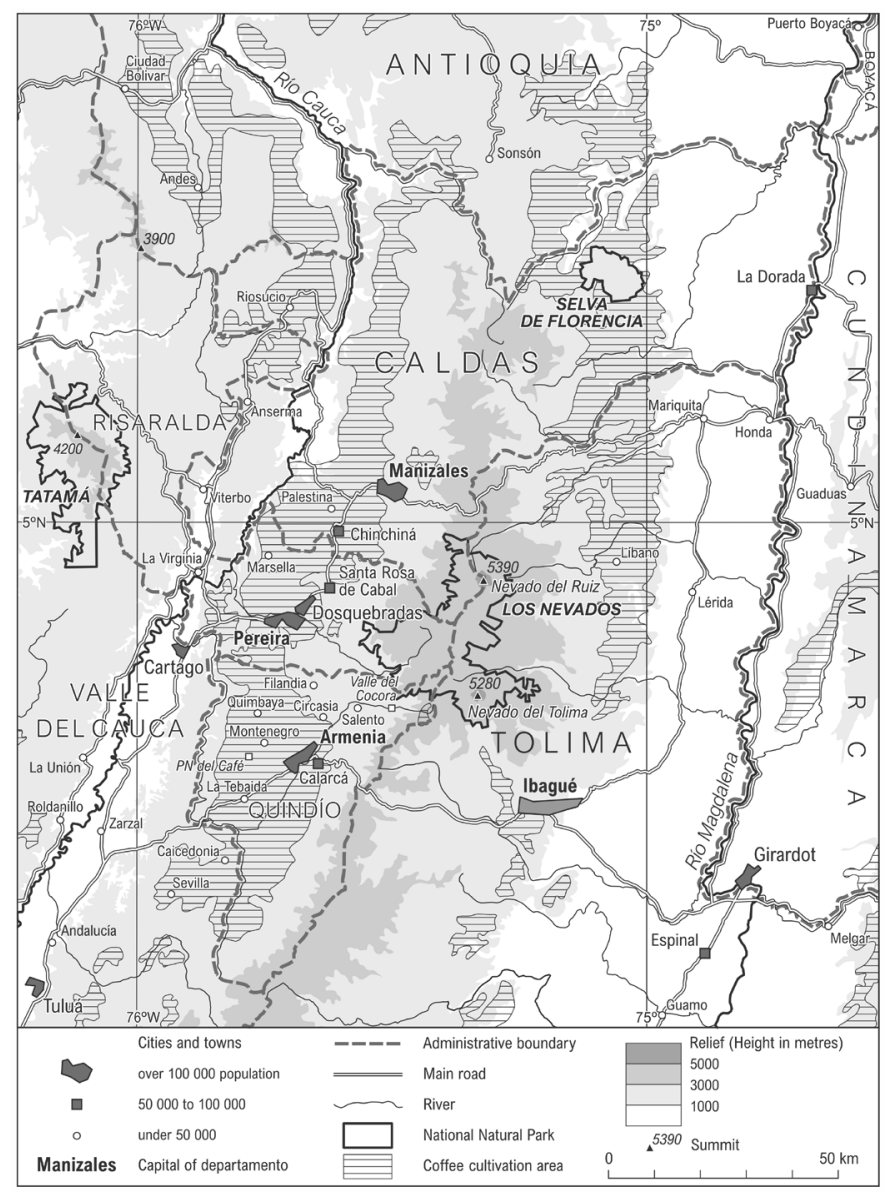

Figure 1. Eje Cafetero in Colombia

Source: own elaboration based on the map Cartografia Base, scale 1:500000 IGAG and the map https://geoportal.igac.gov.co/es/ contenido/datos-abiertos-agrologia.

The Eje Cafetero region was rather colonised late, given that it was only in the mid- $19^{\text {th }}$ century that people came in here from Antioquia Department (located in the north of Caldas) in search of new land they might cultivate. Such land first began to be occupied in the central part of the Central Cordillera of the Andes, and this was forest at that time, and thus needed to be cleared. 
Entire families took part in the process, and the ownership and management model in this part of Colombia has been based on small farms - unlike for example in the Cauca Valley with its large holdings of the latifundia type. Initially it was rubber production that was engaged in here, but coffee began to be cultivated from the late 19th century onwards (Duque, Escobar, 2017).

The living conditions in this region were always difficult since great physical exertion and effort was needed to clear forest and find plantations on mountain slopes. The cultivation process itself is also labour-intensive. This tended to favour large families and close ties between neighbours, and these became hallmarks of a specific regional culture based on strong ties to the place, strong social bonds, and a willingness on the part of people to help each other. Colombian literature referred to this as the cultura cafetera (Duque, Escobar, 2017). On the business side, the activity can be summed up in terms of the emergence of a new social group of small farmers capable of prospering thanks to small plantations that nevertheless generated rather high incomes. This favourable situation was maintained up to the 1970s, when spiralling demand for coffee on the world market encouraged the appearance of new Asian suppliers. Nevertheless, until this day around 600,000 Colombian families live by growing coffee, first and foremost in the Central Andes.

The most important urban centres of this region are Manizales, Pereira and Armenia, which grew up from 1849 until 1903. These localities grew in significance when the railway appeared in the 1920s, but prior to that a 72-kilometre cableway or ropeway known as the Cable Aéreo Manizales-Mariquita had been constructed to transport coffee from the plantations across to port towns on the Rio Magdalena. These efforts did much to raise the profitability of coffee-growing, while also making Manizales a business centre, as well as the cultural heart of coffee region. As of 1920, it had 20,000 inhabitants, whereas Medellín (today Colombia's second city) already had 60,000 people.

The growing importance of coffee as a crop for export allowed local entrepreneurs to prosper, with Antioquia merchant Carlos Eduardo Pinzón controlling 35\% of Colombian coffee exports (primarily to the USA) as of the 1920s. As noted, the coffee trade contributed to the growth of boat traffic along the Magdalena, and into and out of its river ports. A railway was also extended to the Pacific port of Buenaventura, through which around $32 \%$ of all coffee exports was transported in the twenties.

The year 1927 brought the establishment of the Federación Nacional de Cafeteros, which from that day has sought to represent the interests of small-scale producers, on the domestic market, though first and foremost internationally. It is the Foundation that has also played its major role in funding of the construction of roads and bridges, and the organisation of rural schools and health centres, the supply of main electricity, and so on.

However, the situation changed markedly in the 1970s, when a crash in coffee prices globally sent many small farms into the hands of buyers and large agricultural enterprises. Some of the former small-scale producers moved out to large cities at this stage, with declining production of coffee following on from that moment, and a clear trend towards the depopulation of the region's small towns. 
Yet a further fall in coffee prices in 1989 encouraged or forced many coffee-growers into a diversification, in search of extra income. This first and foremost involved the remodelling of traditional farms into establishments able to cater for agritourism and ecotourism. The founding of National Parks - i.e. Parque Nacional del Café in 1995, and Parque Nacional de la Cultura Agropecuaria (PANACA) in 1999 - had the impact on continuous raising interest among both domestic and international tourists. As the years passed, more and more places of landscape and/or cultural value were rendered accessible to visitors, with appropriate infrastructure for tourism put in place steadily. The number of accommodation places in hotels and guest houses was increased, e.g. by more than 1000 at the beginning of the $21^{\text {st }}$ century (https://www.federaciondecafeteros.org/ algrano-fnc-).

Among Eje Cafeteros's three Departments, it is Risaralda that today produces most coffee (43.6\% of the region's sales), followed by Caldas (on 36.5\%) and Quindío (20.1\%). At the same time, it is Quindío Department that has the least-diversified crop structure, with coffee continuing to dominate there until present day. Quindío is also in fact the one to use to the fullest the old coffeeestate infrastructure in seeking to develop tourism. It is here that the largest number of rooms for visitors located in former fincas cafeteras are to be found.

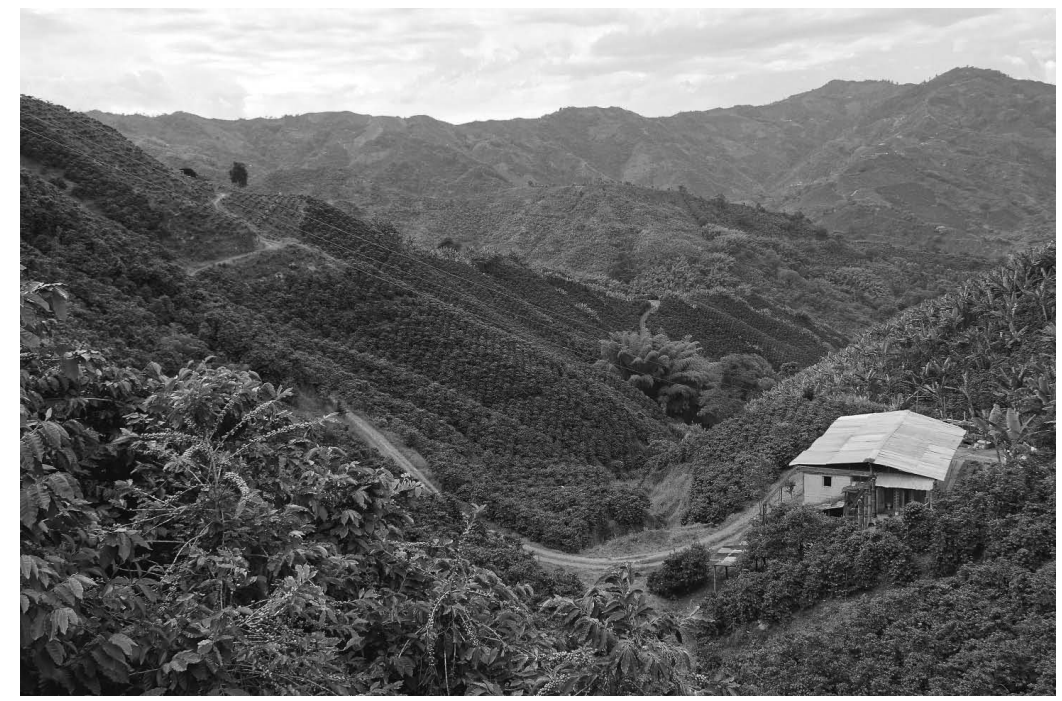

Figure 2. Cultural landscape Eje Cafetero

Source: own elaboration of Mirosława Czerny

\section{Conditions underpinning the development of cultural tourism}

The Eje Cafetero tourist region is often taken as exemplifying a sustainable economy based on existing natural resources and cultural heritage in the landscape of Colombia's Western Andes. Local and regional authorities in the coffee region certainly boast plans and programmes for the development of tourism that recognise the exceptional social, economic and landscape features of this part 
of the country, and the ways in which these support this direction of development as opposed to any other (Martínez, 2006). In so doing, they draw on examples of other countries and regions around the world in which tourism is indeed a product for export (Getino, 1993).

In line with a classical definition of this branch of the economy (Mcintosh, 2006), tourism is a reflection of the fact that people today are constantly in search of new environments and new places in order to familiarise themselves with them. In this way, new contacts with people representing entirely different cultures and customs are made, with alien models at the same time tending to be brought into ever-wider areas. This way tourists enrich their knowledge of the world, and broaden their horizons, with the result that social and cultural relations develop, and come to be based on better and better mutual understanding.

The development of tourism describing itself as "green" thus falls within a more far-reaching aspect of "alternative" tourism (Chavez, 2005; Neira, 2005). Sub-components here would be ecotourism, agritourism and a more general rural tourism. Ecotourism is engaged in by those who particularly value time spent, as they were, in the "bosom of nature".

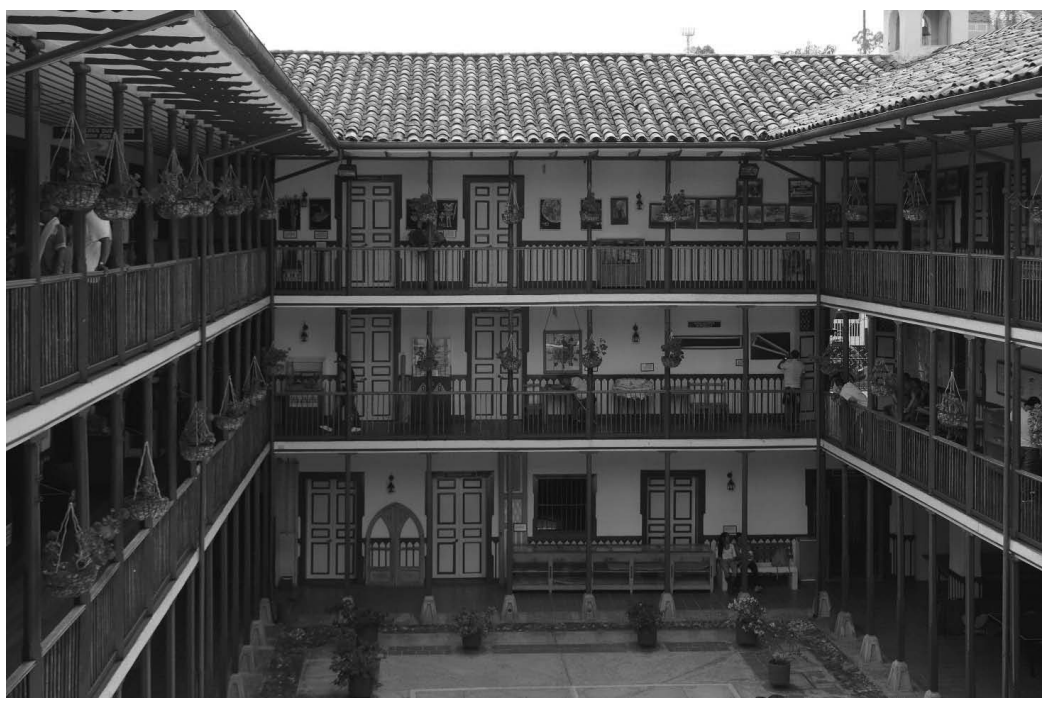

Figure 3. Cultural center in Marsella

Source: own elaboration of Mirosława Czerny.

As early as in 1995, it was clear from a study on the competitiveness of the tourist sector from the Ministry of Development and Tourism of Colombia that support for the development of agritourism and ecotourism in different parts of Colombia was taken as read. The study invoked the success enjoyed by agritourist farms run by German immigrants in Colombia's centrally-located departments.

Unfortunately, the country's political situation, with armed groups active in the drugs cartels and other kinds of organised crime made any such policies look like fantasy, in a circumstance in which free movement across Colombia was not even possible in the early $21^{\text {st }}$ century, with visits 
to beautiful areas in the centre of the country entirely precluded. Even by the 1990s, the coffeegrowing region had become so dangerous and lawless place that any planned development there was doomed to failure. Despite this the launch in 1983 by agrobank La Caja Agraria of a special credit line aimed at supporting the adaptation of plantation farmhouses (fincas cafeteras) to serve the needs of agritourism.

A 1989 crisis on the commodity market for coffee intensified responses to the notion that change in the economic structure of Colombia's coffee-growing region was essential. Alternative sources of income for rural areas had to be sought, and one of those was agritourism, this tended to be referred to in relation to the broader category of turismo verde (Colombia Travel, 2010). For thousands of families in Caldas, Risaralda and Quindío, tourism would indeed become a new source of income eventually.

The best-organised tourist infrastructure, routes and promotion were put in place in Quindío Department. And, on average, this now receives some 800,000 tourist visits a year (with ca. 40,000 of them involving foreigners). All this has left Quindío as the region with the best-developed rural tourism anywhere in Colombia. The Department's 12 Municipalities have put together proposals for diversified ways of spending free time. The Valle del Cocora in Salento Municipality and Salento itself (known for its lines of colourful single-story houses) are attractive to tourists, as well as handicrafts, bamboo products, hats made from palm leaves and embroidered clothing all on display for sale at markets held each Sunday (https://www.eltiempo.com/archivo/documento/ CMS-3606110).

The choice of tourism as an option for the region's economic development also reflects the presence of numerous attractive areas, including that encompassed within the Parque Nacional de Los Nevados, along with several Forest Reserves, as well as land set aside to protect the wax palm (Ceroxylon quindiuense). There are also hot springs and lakes, while the Eje Cafetero region as a whole has a total of 8 theme parks. It was in this way that there arose a new form of tourism proving to be a key factor operating in support of development in the wake of the crisis ushered in by declining exports of coffee.

Of crucial importance to the development of tourism and encouragement of tourist visits and stays are services and technical infrastructure (above all of roads), as well as places to stay, eat, view handicrafts, and so on. Roads prove to be well-developed in Eje Cafetero's case, while airports in Pereira, Manizales and Armenia cater both domestic and foreign tourists. The airport in Pereira lies at the heart of the coffee-growing region and hosts flights from many South and Central American countries. The last ten years have brought a visible further development in road infrastructure here, and the modernisation of existing links. This is especially true for the roads leading to Eje Cafetero's best-known small towns, where town-centre areas have been revitalised, with many additional services for tourists also put in place (e.g. in Filandia, Salento, Chinchina, Marsella and others).

A further key element in the development of "green tourism" has entailed the securing of an overnight accommodation base of suitable size and quality. In the case of Eje Cafetero there were initially guest rooms in coffee-estate farmhouses that were made available. However, as the time 
passed, entire homes were converted into guesthouses. The architecture in these cases is often exceptional, with a ground and first floor, a balustrade around each room, with its own separate entrance, and bright-coloured walls. Such structures are an inseparable element of the landscape in these parts. Today, there are some 20,000 rooms for guests in accommodation of various types. However, given the ongoing growth of tourist traffic, these tend to enjoy $100 \%$ occupation levels. And this is particularly the case in the Department of Quindío, whose whole economic structure has changed in line with adaptation for the development of tourism (Colombia Travel, 2010).

The authorities in different Departments are joined by associations within the tourist sector in pursuing an intensive marketing campaign that seeks to bring in visitors. Key advantages of the region which made use in the campaign are as follows: the cultural traditions based on the agricultural profile of this zone, as well as the specifics arising from coffee-growing; the cultural heritage; and the fine mountain landscapes. The most intensive advertising is that pursued by Quindío tourist office, which promotes visits to plantations, agritourism, visits to other buildings associated directly or indirectly with coffee-growing, theme parks and protected areas, not to mention Café National Park, or the Cocora Valley in Salento (Fuentes Guerra, 2017). There is now a map showing the locations of restaurants, hotels and other items of tourist infrastructure. The Cámara de Comercio de Armenia Chamber in turn proved to be able to pursue with some success its project - Rutas del Paisaje Cultural Cafeterio. In 2014, it reached finals in the competition organised by the International Tourist Organisation to find the best forms of tourist management. Involved here is the delineation and ultimate opening of 6 tourist trails featuring items of heritage built in the region (Giraldo López, Marín Aguirre, Yepes Montoya, 2015).

The year 2017 in fact proved a breakthrough year for Quindío when it came to numbers of foreign tourists. Over a year, the numbers of tourists whose destination was Colombia increased by $20.7 \%$, with Eje Cafeterio visited by 41,000 foreign tourists (mainly from the USA) in 2017. Numbers of visitors originating from Europe also grew (http://caracol.com.co/emisora/2017/11/16/pereira/). In turn, data from the Colombian Statistical Institute dated 24.11.2017 make it clear that there were 6\% more tourists visiting Quindío than there had been in 2016 (http://www.cronicadelquindio.com/ noticia-completa-titulo-6).

During the international tourism fair of the Asociación Colombiana de Agencias de Viajes $y$ Turismo held at Anato in 2018, the Eje Cafetero region had a stand in the international pavilion for the first time; while the Paisaje Cultural Cafetero became the third most important destination in Colombia, after Cartagena and San Andrés. In turn, in Risaralda Department, the coffee-plantation landscape has been enriched by tourist trails along which birdwatching can take place. This is naturally of particular interest to foreign tourists. Also small towns of this region are subject of promotion, and the most notably - Marsella (http:/caracol.com.co/emisora/2018/02/22/ pereira/1519298187). 


\section{The role of small towns in the development of tourism}

This UNESCO-listed part of Western Colombia coffee-growing region has thus been proving very attractive to tourists, on account, not only of the beauty of a landscape in which coffee plantations stretch to the horizon, but also of the cultural heritage in both material and non-material form that for more than a century now has been a part of a life here sufficiently unique to form a distinctive feature of this region inhabitants.

The traditional cultivation of coffee bushes here was focused around family farms located on often very steep slopes of the cordilleras. Farms here were never large (mostly of just a couple of hectares in size). Coffee was brought to local towns on the backs of mules, two sacks per animal (each weighing about $60 \mathrm{~kg}$ ). To this day, the measure describing both the production and export of coffee is the sack of this weight. Thus, a 12-month period of 2017/2018 saw some 14.3 million sacks of coffee produced (https://www.federaciondecafeteros.org/algrano-fnc-).

Material architectural heritage of the region thus includes the rural homes of coffee-planters on plantations now largely transformed into hotels and guest houses, as well as small towns most often located on elevations, in which coffee warehouses are located, and sales take place. The small towns in question rendered - and continue to provide - the services required by surrounding plantations. With a view to tourists being drawn to Eje Cafetero, farmers' houses have been restored and modernised. Indeed, whole small towns have fared likewise, with local-authority support paying off in order to locate many TV series and festivals here, as well as R\&R facilities for Colombians and foreign tourists alike.

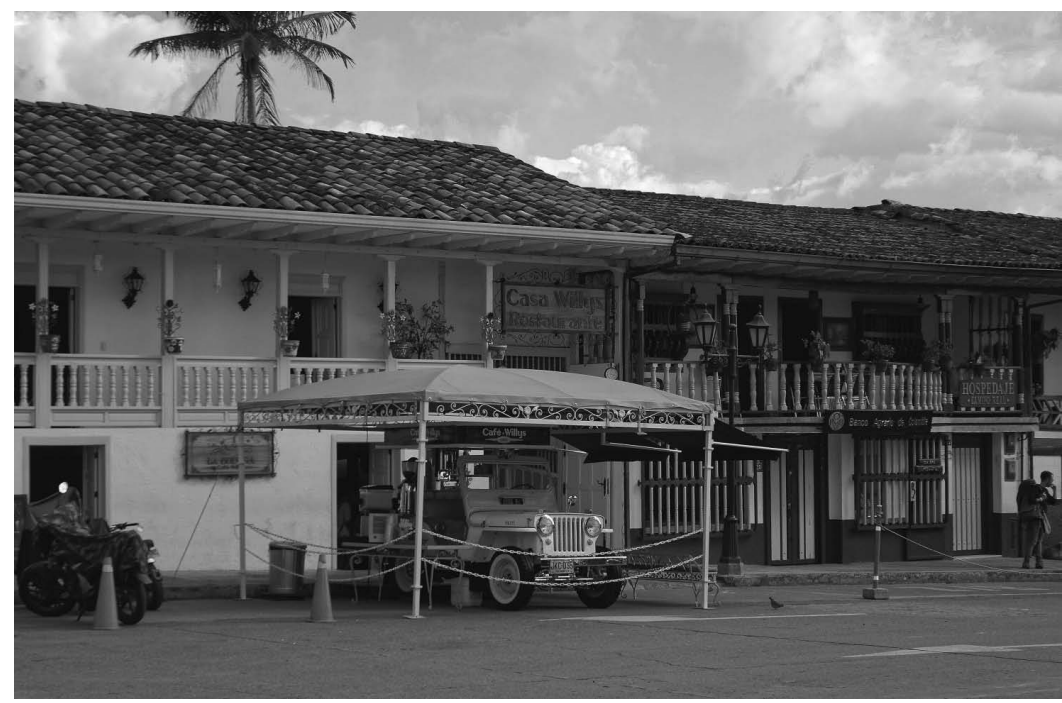

Figure 4. Central square in Filandia

Source: own elaboration of Mirosława Czerny. 
To analyse the influence of such cultural heritage in the development of tourism in this region, three small towns of Filandia, Salento (Department of Quindío) and Marsella (Risaralda) were selected for study, given their status as the most-visited urban centres in Eje Cafetero. All of these have been restored and renovated on a larger scale, and photographs of these places gain most frequent use as promotion of tourism in this region. These areas are indeed thronged with tourists on Sundays and feast days. Then, places to park a car and tables in restaurants prove to be in short supply. In Salento, the region's most colourful locality, the first week of 2018 alone had some 120,000 tourists (very largely domestic) flooding in. The town had to absorb some 1400 private cars and microbuses. And this was definitely not a unique circumstance, given the similar influx noted at Eastertime (http://www.cronicadelquindio.com/noticia).

Table 1. Numbers of vehicles arriving at Salento during Easter celebrations, 2016-2018

\begin{tabular}{|c|c|c|}
\hline Year & Cars & Motorcycles \\
\hline 2016 & 12873 & 5171 \\
\hline 2017 & 11022 & 4819 \\
\hline 2018 & 13983 & 3182 \\
\hline
\end{tabular}

Source: http://www.camaraarmenia.org.co/noticia-detalles-id-1488.htm.

To seek confirmation of hypotheses regarding economic growth in the small Eje Cafetero towns, short interviews were run in March and August 2018 in Marcella, Filandia and Salento, with a view to the issue of tourist traffic being raised with employees of local gastronomic outlets, Jeep and bus drivers, and those engaged in the sale of souvenirs. Conversations were also held with inhabitants met more randomly in central squares. The 30 or so interviews combined with observations made support the observations that:

1. There has been a revitalisation of small towns in the 1950s spirit, with colourful homes, wooden balconies, cafes on the ground floors of buildings around the central square, street traffic dominated by Willys Jeeps loaded with coffee and other goods, and farmers equipped with the traditional attributes of the coffee-grower (i.e. the carriel - a leather bag with many compartments and the mulera cotton shawl, also serving to shield the eyes of mules heading down the steep slopes loaded with sacks of coffee) - all with a view to generate a nice, colourful local atmosphere that attracts tourists (albeit more domestic than foreign thus far, with people from all over Colombia drawn to the place in a desire to stroll the streets, eat meals and - above all - taste the ubiquitously-served coffee).

2. Safety, the openness of Eje Cafetero inhabitants and a diverse cultural offer (including museums, galleries, folk-ensemble performances and the tradition of time being spent together in public space) represent further attributes of the towns in question.

3. A wealth of folk handicrafts (including hat making and the production of items from wool and cotton) combine with a diverse culinary offer to further attract tourists.

This in turn suggests that what tourists are seeking in the small towns of this region, i.e.: 
- various different ways of spending free time, as well as a broad range of gastronomic options,

- safety, and attractive ways in which free time can be spent by the whole family, and families with children in particular (engaging in riding, trips by Jeep or the type of country bus known as the chiva),

- other attractions - like performances by music groups, displays of dancing, local folk costumes, and exhibitions or fairs featuring local craftsmanship, etc.,

- opportunities to visit theme parks.

\section{Conclusions}

Interviews carried out in the small towns of Filandia and Sarento show that foreign tourists purchasing trips before they arrive in Colombia are accommodated on coffee estates, where they spend one or two weeks, visiting the plantations, witnessing the process how coffee is made ready for sale, and participating in some of the work in the fields. In contrast, domestic tourists visit the region's small towns on Sundays and holidays to participate in fiestas, religious or national observances, in this way enjoying the gastronomic services on offer, and purchasing items of local crafts (Pérez, Valencia, González, Cardona, 2014).

The question arises whether the mass tourism involved here is in line with plans for the development of sustainable tourism in this region, as referred to in the first part of this article Regional authorities indeed have ambitious plans in which the sustainable development concept is heralded and slated for implementation; yet other voices note only the en masse nature of the real-life phenomenon. In fact, the responses of inhabitants and the discussions found on blogs readily sustain the conclusion that mass influxes of tourists into these beautiful places are actually leaving them threatened to an even-greater degree.

Locals recall how just 25 years ago the landscape was featured by caravans of mules carrying the sacks of coffee on their backs, coming into the centres of small towns where the beans were offered for sale. They were then set out to dry on pavements and squares, and life in general followed its own slow and steady pace, as accompanied by the drinking of a cup or two of tinto (a small coffee). The tourist boom was ushered in 1999, when interest in coffee tourism exploded and peace came after decades of civil war in Colombia. While this was first a domestic phenomenon, the international version soon took off. Thus did hordes of visitors begin to arrive even just months after hostilities finally ceased. At no point since then have numbers of tourists stopped increasing. So farmers abandoned their small plots of coffee bushes and made their homes into guest-houses. Tourism was able to generate more profit than the sale of coffee. While the daily wage of an agricultural labourer employed to pick coffee was 12,000 pesos (or some \$6) - after deduction of the costs of a meal during the working day, today's car-park employee receives 2000 pesos (around \$0.70) per car. The animals once used to get around plantations or transfer harvested coffee now take tourists to more-distant coffee estates where local people perform dances and sing, while showing off traditional ways of making coffee ready for consumption. 


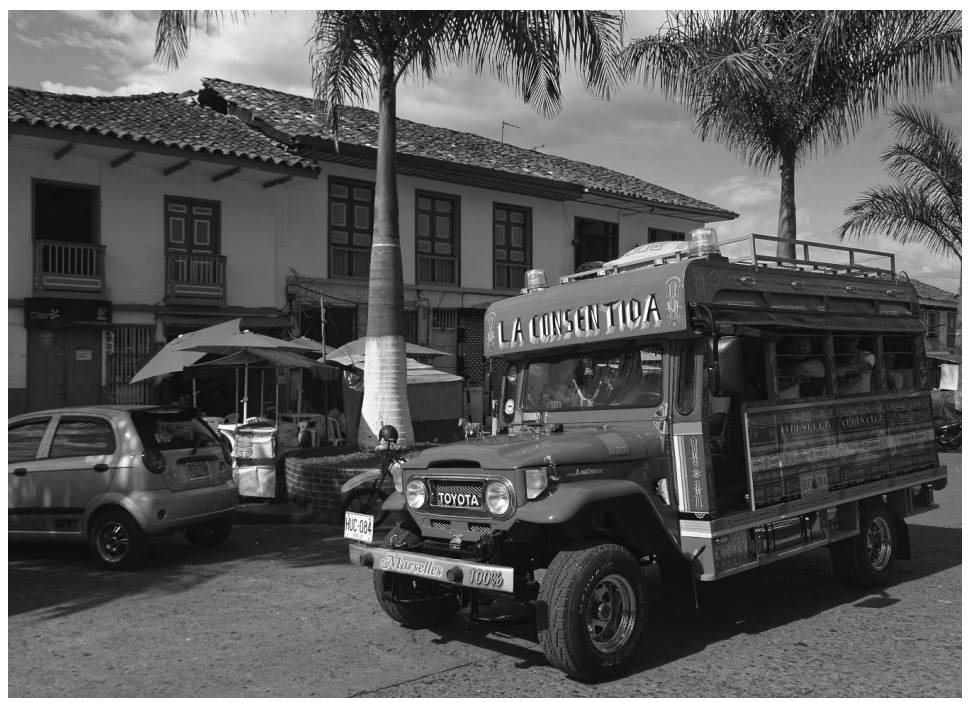

Figure 5. Jeep adapted to carry passengers

Source: own elaboration of Mirosława Czerny.

The boom in tourism in Salento, Filandia and other small towns has also boosted the realestate market, with enchanted foreigners offering prices for houses and coffee estates that are $500 \%$ higher than the original ones noted in the region (Alvarez, 2018). It is common for houses of this kind to be renovated and made over into hotels, though some are also used as second (holiday) homes. As of 2018, 17.2\% of the foreign tourists visiting Salenta were Americans, while 16.6\% were Germans and 13.2\% French. Remaining tourists were from countries of South America, or else from Canada. In the case of Filandia, the figures were in turn 21.4\% for Spaniards and 16.3\% for Americans, as well as $13.3 \%$ French and $10.2 \%$ Germans. It is from among these nations that we find the majority of those settling more permanently in Eje Cafetero (https://www.elquindiano. com/noticia/6381/espanoles-y-estadounidense).

The outmigration of coffee-planters to the large cities like Pereira, Armenia and Cali has intensified, notwithstanding the fact that the jobs of such people are not very good. This has ensured that returns to the coffee-growing regions represent a quite widespread phenomenon, and one that involves former owners of land coming back as hired labour. In the sources cited above, women are reported to have returned to the homes they once resided in, which had been converted into hotels in the meantime, ensuring that the immigrants found work in them as maids or cooks.

Considerable influxes of capital into the region ensure a rising cost of living. Quite often, the amount of money to be earned from tourism is insufficient to cover the costs of housing services and food (Alvarez, 2018). And, as in other places in Andean South America "discovered" by mass tourism (Cordova Aguilar, Czerny, Czerny, 2018), so here as well projects involving the construction of large hotel complexes have come into being. Decamerón and Hilton plan to build hotels 
able to accommodate 1400 guests, within the Cocora National Park. For now, protests on the part of Salento have held off works in order to put these plans into effect.

The social and economic problems indicated here (which also arose with the tourist boom) exemplify over-intensive tourist utilisation of a quite limited area that possesses high-quality cultural attributes. Furthermore, the plans for further development are seen to depart markedly from the sustainable development concept. Nevertheless, the development of local pro-environmental tourism seeks to bring in projects that limit the potential harm done by a considerable influx of guests into the Eje Cafetero cultural landscape. In recent years, an education programme promoting the idea of nature conservation has been devised, with care to be taken of both cultural and natural heritage, and with both local traditions and local resources being promoted. These elements of projects for the development of tourism do fall within the concept of ecotourism in the region under consideration (Sandoval, 2006).



Figure. 6. Manizales, coffee is served not only in cafes, but also from jeeps and trolleys in squares and streets of cities of Eje Cafetero

Source: own elaboration of Mirosława Czerny.

\section{Referencences}

Álvarez, Andrés Felipe (2018). Retrieved from: http://blogs.eltiempo.com/viaje-ha-sido/2015/01/07/salento-turismo-sipero-no-asi/ (7.11.2018).

Arango Gaviria, O. (2008). Eco-región eje cafetero: una experiencia de desarrollo regional en Colombia. ACE, 7, $199-220$.

Ateljevic, I. (2000). Circuits of tourism: stepping beyond the "production/consumption" dichotomy. Tourism Geographies, 2 (4), 369-388.

Britton, S. (1991). Tourism, capital and place: towards a critical geography of tourism. Environment and Planning D: Society and Space, 9, 451-478.

Cardona Lenis, N.C., Valencia, D. C., Salazar Uribe, A., Arias Toro, A.M., Vásquez, J.A., Villota, F., Loboguerrero, A. (2013). Análisis del sector turismo en el Eje Cafetero. Grafías Disciplinares de la UCP, 22, 49-54. 
Chavez, J. (2005). Ecoturismo. México: Trillas.

Colombia Travel, (2010). Retrieved from: www.colombia.travel/turismo-verde.

Cordova Aguilar, H., Czerny, M., Czerny, A. (2018). El desarrollo sostenible de una región con gran potencial turístico. El caso del Valle del Colca. In: M. Czerny, C.A.Serna Mendoza (eds.), Globalización y Desarrollo Sostenible (pp. 159-180). Warsaw: Wydawnictwo Uniwersytetu Warszawskiego.

Escobar, G. (2017). Eje Cafetero: construcción social e histórica del territorio. Revista Summa Iuris, 1 (5), 1-14.

Fuentes Guerra, J. (2017). Alojamiento turístico en el Eje Cafetero de Colombia. Cádiz: UNIR.

Getino, O. (1993). Turismo y desarrollo en América Latina. México: Editorial Limusa.

Giraldo López, V., Marín Aguirre, V., Yepes Montoya, X. (2015). Caracterización de la estructura socio-económica del turismo en el Departamento de Risaralda. Pereira: Universidad Tecnología de Pereira.

Graham, B., Ashworth, G.J., Tunbridge, J.E. (2000). A Geography of Heritage. Power, Culture and Economy. London: Arnold.

Harvey, D. (1989). From managerial to entrepreneurialism: the transformation in urban governance in late capitalism. Geografiska Annaler, 71, 3-17.

Harvey, D. (1993). From space to place and back again: reflections on the condition of postmodernity. In: J. Bird, B. Curtis, T. Putnam, G. Robertson, L. Tickner (eds.), Mapping the Futures: Local Cultures and Global Change (pp. 3-29). London: Routledge.

Jackson, P, Thrift, J. (1995). Geographies and cultural politics of advertising. Progress in Human Geography, 3 (20), 356-371.

Kumar, A., Welz, F. (2001). Culture in the world-system: An interview with Immanuel Wallerstein. Social Identities, 2 (7), 221-231.

Mcintosh, R. (2006). El turismo, planeación, administración y perspectiva. Mexico: Editorial Limusa S.A.

Martínez, V. (2006). Ocio y turismo en la sociedad actual. Madrid: Interamericana de España.

Estudio de la competitividad del sector turismo, t. 2. (1995). Bogota: Ministerio de Desarrollo y Turismo.

Neira, M. (2005). Ambito turistico. 2nd edition. Pereira.

Pérez, V. G, J., Valencia, F., González, B., Cardona, J.C. (2014). Pereira: contexto actual y perspectivas. Documento de trabajo sobre economía regional. Cartagena: Banco de la Republica.

Sandoval, E. (2006). Ecoturismo, operación técnica y gestión ambiental. Mexico: Trillas.

https://www.elquindiano.com/noticia/6381/espanoles-y-estadounidense (7.11.2018).

http://www.camaraarmenia.org.co/noticia-detalles-id-1488.htm (6.11.2018).

http://caracol.com.co/emisora/2017/11/16/pereira/1510853481_360009.html (6.11.2018).

http://caracol.com.co/emisora/2018/02/22/pereira/1519298187_538380.html (6.11.2018).

http://www.cronicadelquindio.com/noticia-completa-titulo-6_creci_la (26.09.2018).

http://www.cronicadelquindio.com/noticia-completa-titulo-se-espera-la-visita-de-hasta-120-mil-turistas-en-salentonota-116854 (6.11.2018).

https://www.eltiempo.com/archivo/documento/CMS-3606110 (6.11.2018).

https://www.federaciondecafeteros.org/algrano-fnc-es/index.php/comments/produccion_de_cafe_de_colombia_aumenta_36_en_junio/ (31.10.2018). 


\section{DZIEDZICTWO KULTUROWE A ROZWÓJ TURYSTYKI ZRÓWNOWAŻONEJ W REgionie El EJE CAFETERo, W KolumbiI}

\author{
SŁOWA KLUCZOWE
}

STRASZCZENIE dziedzictwo kulturowe, turystyka kulturowa, rozwój zrównoważony, kraje rozwijające się, Eje Cafetero

Na dziedzictwo, jako jeden z elementów kultury, należy spojrzeć przez pryzmat jego potencjału ekonomicznego i możliwości kreowania gospodarki lokalnej i regionalnej. Krajobraz kulturowy, szczególnie promowany i ceniony przez ludność miejscową i przyjezdnych stanowić może również obiekt dziedzictwa. Niewątpliwie jest nim region uprawy kawy w zachodniej Kolumbii. El Eje Cafetero - zadeklarowany obiektem dziedzictwa kulturowego przez UNESCO stał się jednym z najbardziej popularnych destynacji turystycznych w tym kraju.

Region turystyczny Eje Cafetero, przedstawiany jest często jako przykład zrównoważonej gospodarki opartej na istniejących zasobach naturalnych i dziedzictwie kulturowym w krajobrazie andyjskim zachodniej Kolumbii. Władze departamentów i municypiów „kawowych” w przyjętych planach i programach rozwoju turystyki w regionie, uznając wyjątkowość cech społecznych, gospodarczych i krajobrazowych tej części kraju wspierają taki właśnie kierunek rozwoju (Martínez, 2006), biorąc przykład z innych krajów i regionów świata, gdzie produktem eksportu jest właśnie turystyka (Getino 1993).

Celem artykułu jest analiza i ocena wpływu rozwoju turystyki kulturowej na rozwój regionu tradycyjnie rolniczego, gdzie dominowała uprawa kawy. 